\title{
Refugee Movements from the Sudan: An Overview Analysis
}

\author{
Ogenga Otunnu
}

\begin{abstract}
Most refugees do not leave their home with a national passport in hand. Nor do they have prepaid tickets for their transport since they do not take national airlines or railways when they leave their countries. They leave in acute situations and for many of them their journey is hampered by acute problems. They flee in disguise, avoid the main roads; and are ignorant of what lies ahead since they travel through unknown territory often without guide. This makes flight for many a grope for safety in total darkness. And such flight is filled with numerous hardships and danger. (Bulcha, M. 1988. Flight and Integration: Causes of Mass Exodus from Ethiopie and Problems of Integration in the Sudan. Uppsala: Scandinavian Institute of African Studies, 138.)
\end{abstract}

The Sudan is the largest country in Africa, and was one of the earliest to obtain formal independence (1956). Like the rest of the countries of the Horn, it is one of the poorest in the world, with a chronically dependent agrarian economy. Its pre- and postindependence history has been characterized by almost unpunctuated bouts of high-level political violence; religious, racial, ethnic and ideological conflict; ecological crisis; economic decay; and external intervention. The interplay of these complex but related factors, past and present, has left a trail of human suffering: loss of lives, flight and internal displacement. The ferocious momentum of the crisis has defied half-hearted, ill-conceived and ideologically driven attempts at conflict resolution, early warning and economic development in the country. The failure to address the causes of the tragedy has, therefore, allowed the refugee crisis and internal displacement to blossom in the rugged and hostile desert soil of the Sahara. It has also exacerbated the political and economic marginalization of the country. ${ }^{1}$

The majority of the uprooted who managed to cross international borders circulated within the same ecologically, economically and politically turbulent states of Ethiopia, the Central African Republic, Djibouti, Egypt, Kenya, Uganda and Zaire. These host countries, like most states in Africa,

Ogenga Otunnu, a PhD candidate in the History Department, York University, is a research associate at $C R S$. were themselves desperately poor and faced severe political and social upheavals on the domestic front. In fact, some of these countries, including Ethiopia, Uganda and Zaire, were so unstable that they also generated and sent hundreds of thousands of refugees to the Sudan. A constellation of complex and harrowing factors also forced some Sudanese to migrate to the Gulf states. There were also a few who traveled the difficult and uncertain route to the industrialized states of Europe and North America. ${ }^{2}$

What were the causes of refugee migrations and internal displacement in the Sudan? Why does the crisis persist? At what point did the refugees flee their country? How did they flee? Where did they go? These are some of the questions this article seeks to examine within the national, regional, continental and international contexts. Lack of adequate data on Sudanese refugees in Europe and North America, however, constrain this study.

\section{The Political History: An Overview}

The genesis of the contemporary internal displacement and refugee-producing crisis in the Sudan may be traced to the turn of the nineteenth century. This era witnessed increasingly violent contact with the external world. During this period of external penetration and expansionist imperialism, the Sudan came under the ineffective, corrupt and autocratic Turco-Egyptian rule. A number of developments characterized this period of conquest. First, the conquest and occupation of the territories were carried out through violence and manipulations. The outcome of the encounter between the indigenous and external forces led to flight, loss of lives and internal displacement. This is not to suggest that the encounter did not benefit the local "collaborating class" that seized the new era to plunder and accumulate wealth for itself. Second, the timing and tempo of the external penetration of the non-Arab and non-Moslem South were influenced by the quest for slaves and ivory. Slaves were obtained through slave raids that led to loss of lives, destruction of property and socioeconomic and political systems, and generated internal displacement and refugee movements. This legacy of the NorthSouth encounter created a wide gulf between the two Sudan. Third, for the first time in the history of the territories, peoples of diverse and heterogeneous nationalities, and at times with competing historical experiences, were forcibly lumped together. This was the forerunner to the colonial state formation, laden with tensions and conflicts. Finally, economic, religious, cultural, migratory and geographical links between northern Sudan and the Muslim region of the Middle East brought the former under the ambit of the Middle East geopolitics. ${ }^{3}$

The next major phase of the external penetration, conquest and occupation of the country was during the new era of European imperialism, in particular, the last three decades of the nineteenth century. This epoch of intense and feverish European rivalries for global economic and political power brought the Sudan into the family of territories to be parcelled out among imperial powers. Among other things, the Sudan was of considerable strategic importance because of its links to the Nile, Egypt and the Suez Canal. Its proximity to the Red Sea was of addi- 
tional significance to the imperial strategy. Two intervening developments influenced the timing of European conquest and occupation of the country. First, the bondholders economic crisis in Egypt jeopardized the security of the Canal and led to the AngloEgyptian war of 1882. Armed with gunboats and maxim guns, the British decisively won the war and occupied Egypt. Second, the Mahdist revolution in the Sudan challenged Turco-Egyptian hegemony and sent shock waves to the citadel of British power in Egypt. The cardinal objectives of revolt or the jihad; led by Mohammed Ahmad alMahdi (1881-1885), were the revival and purification of Islam and its spread to the whole world, by force if necessary. The unstated but equally important objective was the resistance to the abolition of the slave trade that had benefited the northern ruling elite and the economy of the area. To achieve the stated objectives of the revolt, the first battle was waged against the infidels, especially the alien rulers. The revolt or resistance that threatened the security of the Suez Canal was suppressed by combined Anglo-Egyptian troops in 1889. The effects of the revolt included heavy loss of human lives, flight, internal displacement, the emergence of a new and local "collaborating class," the expansion of Islam as a religious and a political ideology in the Sudan and the British occupation of the Sudan. ${ }^{4}$

During the British rule, a dual colonial administrative policy of divide and rule was developed for the country. The North was administered by local colonial agents, appointed from the ranks of those Muslims who had opposed the Mahdist revolt and collaborated with the colonial regime. The South on the other hand was administered using the "Closed Door" policy or the "Southern Policy." This Southern Policy, which was abandoned only after World War II, attempted to insulate the region from Arab and Islamic domination. One of the colonial ideological strategies used to insulate the South from the North was the spread of Christianity. The contradictory colonial policy, among other things, insulated the South from economic development, leaving it in a severely disadvantaged position and strengthening the North-South divide. Later attempts to integrate the two Sudan, therefore, would not only be difficult and elusive, but also violent. ${ }^{5}$

When the 1949 Ordinance established the Legislative Assembly to provide space for limited political participation of Sudanese in government, it became clear that the two Sudan had different political visions. For example, while the North felt that its economic and political advantage would be enhanced in a unitary state, the South knew that its marginal position could only be improved in a federated state. In the end, however, the direction and tempo of the debate was decided outside the corridors of the Legislative Assembly by the 1952 Nasser revolution in Egypt. The politi$\mathrm{cal}$ and security tremor the revolution generated sent two important messages to the regime. First, that it was living on borrowed time in the region. Second, that the honourable way out of the crisis was to craft an independence agreement for the Sudan before the revolution became contagious. In retrospect, the impetus for the 1953 Agreement, which paved the way for the 1956 independence, was mainly the result of the imperial contradictions elsewhere. By accident of colonial history, the terms of Agreement largely reflected the concessions the British made to the northern Sudanese. ${ }^{6}$

On the eve of independence in 1955 , the self-government of Ismail el-Azari ordered the southern Command to relocate to the North and the replacement of British military officers in the South by Northerners. This order, however, provoked existing grievances about the alienation of the South and resentment of northern domination. As a result, the soldiers mutinied in Torit and other military posts in the South. The state responded with brutal violence to crush the resistance. A number of points should be highlighted from this revolt. First, the vio- lence that dragged on into the postcolonial era symbolized the birth of a post-independence state chained in the contradictions of the colonial state. Second, while the arrival of independence was celebrated by the North, the South buried their dead and fled. As such, independence meant different things to the two Sudans. These developments suggested to the South that without access to the resources allocated by the faltering postcolonial state, it had no future in that country. Third, the ideology of nonviolent struggle for fair representation, economic development and federalism in the South was now resting on bare soil. Indeed, socioeconomic and political demands would be negotiated in the battle fields. The imminent danger of such a negotiation was that it could not bring about lasting solutions to the conflict. Equally, the war that consumed much of the scarce national resources made a mockery of development programs. Finally, this period marked the demise of the nascent civil institutions. It also announced the beginning of major refugee movements to the neighbouring states of the Central African Republic, Uganda and Zaire. $^{7}$

The regimes of Abdallah Khalil and his military ally, Gen. Ibrahim Abboud (1956-1958 and 1958-1964), were paralyzed by endless ethnic, religious and ideological competitions. During this period, a number of events redefined the terrain of political struggles and violence in the Sudan. First, the northern-dominated Constitutional Commission rejected the demand for federalism. In a symbolic way, this dealt a devastating blow to the demands of the South. Second, the escalation of military repression in the South provoked increased armed struggle in the area and led to the formation of the Any-nya. This armed group received direct and indirect political and military support from Israel, Ethiopia, Kenya and Uganda, thus further internationalizing the conflict in the country. Admittedly, this led to increased violence which in turn uprooted more people. Third, the 
state assumed full responsibility for education in the South. Thereafter, secondary schools were relocated to the North. This policy undermined human development in the South and sparked off a mass exodus of students to Uganda and Zaire. Fourth, the state imposed Arabic as the state language and Friday as the weekly day of prayer and rest. Among other things, this policy forced most of the southern elites who had been trained in the English language to flee to neighbouring states. Fifth, the devastating famine and flood of 1962-1963 in the South uprooted many people. This combination of human-made and ecological disasters exacerbated the crisis in the South. Finally, the cost of the civil war, the poor harvests of 1963 and 1964, and the foreign exchange crisis produced serious political and economic upheavals in the North that finally led to the capitulation of the Abboud regime. $^{8}$

Similar socioeconomic and political upheavals devoured the regimes of elKhatim el-Khalifa (1965), Ahmad Mahgoub (1965-1966), Sayed Sadiq Al Mahdi (1966-1967), Mohammed Ahmad Mahgoub (1967-1969) and Abubakar Awadallah (1969). To be sure, between 1967 and 1968, halfhearted attempts were made to reach a negotiated settlement with exile opposition groups from the South. This move, however, failed because of four main reasons. First, the state was not committed to reaching a comprehensive settlement. In fact, the impetus for the negotiation came from the growing and persistent cost of the war in the South; chaos within the army; economic hardships, aggravated by the closure of the Suez economic lifeline during the 1967 Arab-Israeli conflict; and ideological and religious conflict in the North. Second, although the South had a "common enemy," it was utterly divided along ethnic, ideological and class lines. As a result, it was only the faction of the Sudan African National Union (SANU, previously known as Sudan African Closed District Union) led by William Deng that embarked on a serious but futile nego- tiation with the state. Third, the Anynya took advantage of the ceasefire and chaos within the army and stepped up its military campaigns in the area. The response by the military, among others, resulted in the Juba and Wau massacres. Fourth, Khartoum was too preoccupied with the ArabIsraeli conflict to devote any meaningful effort in seeking a settlement with the South. The regime was rewarded for its participation in the Arab-Israeli conflict with massive military and financial assistance from Algeria, Egypt, Saudi Arabia and Kuwait. The assistance fuelled and greased the war machine in the South. Also, Sudan's support of the Arabs led to the collapse of diplomatic relations with the USA. In keeping with the Cold War power politics, the USSR promptly rushed in and occupied the power vacuum, thus widening the scope of the conflict. ${ }^{9}$

In May 1969, Col. Ja'far Nimeiry seized power with the support of the Sudan Communist Party (SCP) and promised to tackle the problems of the country within a socialist framework. His reign was defined by a number of developments. First, on February 27, 1972, the Addis Ababa Agreement was signed between the regime and the majority of opposition groups from the South. The Agreement essentially ended the civil war that had raged from 1955 to 1972 . It also facilitated the resettlement of some 500,000 to 800,000 internally displaced persons in the South and the repatriation of hundreds of thousands of Sudanese refugees from the neighbouring states. The Agreement further provided space for a considerable flow of international assistance to southern Sudan. Second, with the common enemy barricaded by the Agreement, internal contradictions and power struggles within the South erupted. This provided the regime with the opportunity to manipulate and exploit ethnic and ideological differences in the South, while at the same time, assuming the role of referee in the local power conflict. Undoubtedly, the conflict in the South prolonged the life span of the regime. Third, a protracted opposition devel- oped in the North-especially from the Muslim Brotherhood-to the terms of the Agreement that provided autonomy to the South and recognized historical and cultural differences between the two Sudan. In an attempt to deter the growing and immediate threat to its existence, the regime caved in to the demands of the Islamic fundamentalists in the North, and imposed Arabic as the national language and the Sharia laws of Islam upon the country.

Fourth, the settlement gradually collapsed beneath its own weight due to a series of related events: the discovery of huge oil reserves in the South by Chevron in 1970 and the ensuing conflict that emerged concerning the location of the oil refinery; conflict over the construction of the Jonglei Canal in the South to improve the flow of the Nile to the north and Egypt; and the dismissal of the Southern Assembly and the dissolution of the Regional Government by the regime in October 1981. Fifth, the regime ordered southern Sudanese soldiers to relocate to the North. The order was promptly disobeyed and the day of reckoning arrived with military engagement, the proclamation of the state of emergency in April 1984, and the suspension of much of the constitution. With these last developments, the carcass of the Addis Ababa Agreement lay bare on the hostile soil. The collapse of the Agreement led to loss of life and property, internal displacement and refugee flows.

Sixth, the Sudan People's Liberation Army (SPLA) emerged under the leadership of Col. Dr. John Garang de Mobior as the most powerful opposition group to the regime. During its formative period, the SPLA eliminated opposition to its supremacy from other southern groups. This was achieved through a combination of negotiation, co-option and violent coercion. Once it had acquired a position of cohesion, organization and dominance, the SPLA secured military, financial and political support from Ethiopia, Israel, Kenya, Libya, the USA and the USSR. Seventh, when the regime proposed a 
union with Libya and Egypt, and a new relationship with the Eastern block, its ally, the SCP, opposed the move towards the proposed union. Conflict between the two led to the short-lived coup of July 1971, the expulsion of the USSR and resumption of cordial relations with the USA and the West. Also, the regime supported the Camp David accord on the Arab-Israel conflict and received massive military and financial rewards from the West. However, as opposition to the accord grew among Islamic fundamentalists and the evacuation of Ethiopian Jews to Israel through Khartoum continued, the regime imposed the Sharia laws as a domestic compromise. With this last development, the regime became a risky liability and was deserted by its conservative Arab allies and the West. Finally, the cost of the civil war, drought, escalating debt service, economic mismanagement and ideological conflict at the helm of the state led to serious social unrest that brought down the regime in April $1985 .^{10}$

The regime of Sayed Sadiq AlMahdi, which assumed power from the transitional military government in May 1986, had a very fragile power base. A number of notable developments took place during the existence of the regime. First, attempts to reach a comprehensive settlement with the SPLA failed due to the shifting power base of the regime, the formation of a coalition government with the Islamic Front in January 1988, and the dawning of a civilian aircraft by the SPLA at Malakal. Second, by the end of 1987, the SPLA had gained an upper hand in the war and had limited the presence of the military in southern Sudan to major towns such as Wau, Juba and Malakal. Third, both sides in the war deployed desperate military strategies including a scorched-earth policy, and the use of food and famine relief to achieve political and military control over the area. This resulted in massive starvation, dislocation, internal displacement and refugee migrations. Most of the refugees fled to Uganda and Ethiopia. Fourth, the regime inherited a state that was practically bankrupt, with a debt of over ten billion U.S. dollars and a war that consumed an estimated one million U.S. dollars a day. The crisis was exacerbated by low world prices for cotton and other export commodities, low production of agricultural raw materials, severe drought and famine and the shutdown of oil wells due to the war and high debt service. In July 1987, the regime declared a state of emergency in order to curb political instability, and to control the flight of foreign exchange, prices of commodities and smuggling. In an attempt to attract more aid to keep the regime afloat for a while, Al-Mahdi improved relations with the West and in return received food and financial assistance. Fifth, the regime also improved relations with Libya, most Arab countries, the Soviet bloc and neighbouring African states (except for Uganda, Kenya, Ethiopia and Chad). Finally, the regime was forced out of power in a military coup in June 1989.11

The military government of Gen. Bashir seized power with the support of the National Islamic Front. With its local ally, the regime imposed a stricter Islamic law throughout the country and embarked on silencing and eliminating its opponents in the North. On the southern front, the regime was able to rout out the SPLA from most of the areas it had previously controlled. Among other things, three factors explained the military success of the regime. First, it received massive military assistance from Libya, Iran and Iraq, thus giving it a clear edge in the war. Second, power struggles within the SPLA weakened the movement. Finally, the collapse of the Mengistu regime in Ethiopia in May 1991 deprived the SPLA of its most important military and political base in the region. In fact, the new governments in Ethiopia and Eritrea were quite hostile towards the SPLA for having assisted the Mengistu regime in military campaigns against them. Since the SPLA also had some control over Sudanese refugees in Ethiopia, the post-Mengistu government induced over 380,000 Sudanese refugees to return to the Sudan. A large number of the returnees were killed by the Sudanese military. The split within the SPLA and the major military setback it is facing have generated massive refugee flows into Uganda, Kenya, the Central African Republic and Zaire (see table 1). ${ }^{12}$

\section{When Did Flight Take Place?}

This question refers to the point at which people were forced to flee from the country. Generally, the "decision" to flee depended on a number of interrelated factors such as one's position in society; the nature, magnitude, duration, speed, location, timing and period of conflict and/or disaster; proximity and accessibility to international borders; opportunity, capacity and ability to flee; individual and collective responses to violence; and formal and informal networks.

As in the rest of the Horn, flight among the Sudanese occurred only when people had exhausted coping strategies. Three groups whose "decisions" to flee at the particular time differed slightly will be highlighted. The first category is what we shall refer to as "elite-cum-student decision." This category was composed of southern Sudanese elites and students whose flight began effectively in the 1960s following the imposition of Arabic as the official language, Islam as the only religion and the closure and relocation of secondary schools to the North. It had become clear to the elites that they would never gain access to statecontrolled jobs and other resources. Consequently, they embarked on migrations to foreign lands. The students were convinced that they could not pursue their education in the new environment. They, too, had exhausted their coping strategies and decided to flee to neighbouring states.

Undoubtedly, both groups made their decision in a situation of civil war. These groups fled to neighbouring African states. Some proceeded to Europe and North America with the help of the UNHCR, religious organizations and informal support networks. ${ }^{13}$ 
The second category is referred to as "labour decision." This category comprised northern Sudanese who fled and / or migrated to Egypt and the Gulf states. Some members of this group were students who went to these countries to study and decided to "overstay" or to proceed to Europe and North America for "further studies." The majority went to the Gulf states and sought employment because of the severe economic and political crisis at home. They were also encouraged by the national labour migration policy. Here, linguistic, religious and cultural ties, proximity and accessibility to international borders and the perception of how to cope with the national crisis were important in the pre-migration decision. Internal conditions in the receiving oil and capital rich countries of Bahrain, Kuwait, Libya, Oman, Qatar, Saudi Arabia and the United Arab Emirates also facilitated the decision to migrate at that particular time. Indeed, these countries experienced rapid economic growth in the 1970s and 1980s, and needed migrant and domestic labourers. Other factors that facilitated the timing of migration were: the liberal labour and migration policies; formal and informal networks; uncontrolled borders and religious pilgrimage to Mecca. Later, however, internal conditions in the Gulf states hindered migrations. ${ }^{14}$

The last category which will be referred to as "mass decision," comprised the overwhelming majority of the southern Sudanese refugees. This group fled in large numbers to the neighbouring African countries due to the harrowing effects of the war. The group fled when it could no longer cope with the violence and disaster which threatened every aspect of their existence. More often than not, the decision to flee was made collectively or in groups. Here, proximity and accessibility to international borders, informal networks, asylum and refugee policies of neighbouring countries, the timing and intensity of the conflict and the location of the crisis influenced the timing of the decision to flee. ${ }^{15}$

\section{What Were the Modes of Fight?}

The mode of flight depended on a number of factors such as the location, speed and intensity of the conflict; the tactics used in the conflict such as targeting main roads and vehicles or mining possible escape routes; the direction and destination of flight; and the capacity to afford a particular mode of flight. The first category, "elite-cum-student," for example, used a combination of transportation including travel by foot and vehicles, and later, by air to North America and Europe. As migrations overseas required travel documents and entry visas, this group sought assistance through the UNHCR, the Red Cross and other NGOs. The second category, "labour decision," often used official channels and controlled exit points. The modes of transportation used included foot, vehicle, boat, ship and air. The last category, "mass decision," walked through the rugged terrain and over long distances. At times, they had to avoid aerial bombardment by travelling at night. The predominant mode of flight was by foot, though occasionally a combination of means of transportation was used. ${ }^{16}$

\section{What Were the Flight Destinations?}

This question provokes two other related ones: Why did they flee to their respective destinations? Why did they not flee elsewhere? As pointed out, the first and third categories fled mainly to the neighbouring African states of Uganda, Kenya, Zaire, the Central African Republic and Ethiopia (see table 1). These destinations were mainly determined by proximity, kinship ties, location of conflict, asylum and refugee policies of the countries and accessibility of international borders. While physical proximity remained constant, other factors changed from time to time. For example, in Uganda, Sudanese refugees were warmly welcomed by the state and their "kinsmen" in the North of the country in the 1960 s. Later, however, hospitality fluctuated depending on the political and secu- rity considerations of the host country. First, during the 1960s, the refugee crisis in Uganda as elsewhere in Africa, was seen as a temporary phenomenon which required temporary solutions. As such, implementation of liberal refugee policy worked to the advantage of Sudanese refugees. Second, Uganda, under the leadership of Dr. Milton Obote (1962-1971), was quite sympathetic to the problems facing southern Sudan. Third, the presence and influence of Israel in Uganda drew the country directly into the Sudanese crisis. It is important to remember that Israel actively provided military and financial assistance to southern Sudan in an attempt to break the anti-Israeli sentiments in the Arab world and Black Africa. Toward the end of the Obote regime, the rise of Nimeiry to power in the Sudan suggested that the two countries could work closely together. This loose ideological alliance was reinforced by two other factors: the deteriorating relations between Uganda and Israel; and Uganda's internal domestic crisis which threatened the Obote regime and demanded friendly relations with its neighbours. These new elements in domestic and foreign relations, curbed refugee flows from southern Sudan to Uganda. On January 25, 1971 Gen. Idi Amin came to power and embarked on expanding the military by recruiting from areas that would not threaten his power. Among the groups recruited into Amin's security organizations were southern Sudanese, Zairians and Rwandese refugees. This factor in the domestic policy favoured refugee flows from southern Sudan. When Amin was overthrown, Sudanese refugees fled back to southern Sudan because they feared retaliation from the advancing Tanzanian and Ugandan armed forces. Also, during the Amin era, the main target was the Luo of northern Uganda. As such, the participation of some southern Luo in the government eroded kinship ties between the two Luo groups. On January 25, 1986, Lt. Gen. Museveni seized power and initiated a positive policy toward southern Sudan. This policy 
was influenced by internal security considerations. To begin with, the groups that were opposed to the Museveni regime had fled to southern Sudan. Therefore, to get rid of such opposition, the regime allied itself with the SPLA to dislodge the Ugandans from southern Sudan. There were three important outcomes of the policy. First, the SPLA attacked the refugee camps in the area, killing a large number of the refugees and forcing hundreds of thousands to repatriate to the war zone in northern Uganda. Second, the SPLA was rewarded with close military and political support from the Museveni regime. Finally, with the major military setback the SPLA suffered, a large number of Sudanese refugees fled to northern Uganda. Migrations of Sudanese refugees to Uganda have, therefore, been influenced by security and political considerations of the host state. ${ }^{17}$

Similarly, flight to Ethiopia could be explained in terms of national, regional and international politics and security considerations; proximity to accessible national borders; and favourable refugee and asylum policies. In fact, until the overthrow of Mengistu, the regimes in Khartoum and Addis Ababa were at each other's neck. According to the dictum of regional power politics: the enemy of your enemy was your friend. Therefore, Sudanese refugees were welcomed to Ethiopia, and correspondingly, Ethiopian and Eritrean refugees were welcomed to the Sudan. However, following the change of regime in Ethiopia, the dictum changed: the enemy of your friend is your enemy or the enemy of your friend is not your friend, hence the forced repatriation of Sudanese refugees. Refugee flows to Zaire and the Republic of Central Africa are explained more in terms of kinship ties, traditional trade routes and proximity, and accessibility to international borders.

Flight to Chad, on the other hand, was hampered by the hostile buffer between the South and the neighbouring state. Here, southern Sudanese had to first penetrate the area under the control of the Khartoum regime before reaching Chad. Similarly, flight to Egypt and the Gulf state would have

\begin{tabular}{|c|c|c|c|c|c|c|c|}
\hline Year & Country of origin & Country of asylum & Number & Year & Country of origin & Country of asylum & Number \\
\hline \multirow[t]{2}{*}{1980} & Ethiopia & Sudan & 303,000 & 1987 & Chad & Sudan & 45,000 \\
\hline & Sudan & Ethiopia & 11,000 & & Zaire & Sudan & 5,000 \\
\hline \multirow[t]{3}{*}{1981} & Sudan & Ethiopia & 11,000 & 1988 & Ethiopia & Sudan & $660,000^{*}$ \\
\hline & Ethiopia, Uganda, & & & & Sudan & Ethiopia & 350,000 \\
\hline & Chad and Zaire & Sudan & 490,000 & & Chad & Sudan & 25,000 \\
\hline \multirow[t]{3}{*}{1982} & Sudan & Ethiopia & 11,000 & & Uganda & Sudan & 3,600 \\
\hline & Ethiopia, Uganda, & & & $1989-90$ & - & data $n / a$ & \\
\hline & Chad and Zaire & Sudan & 500,000 & 1991 & Sudan & Central African Rep. & 5,100 \\
\hline \multirow[t]{5}{*}{1983} & Sudan & Ethiopia & 5,400 & & Sudan & Ethiopia & 398,000 \\
\hline & Ethiopia & Sudan & 350,000 & & Sudan & Uganda & 64,000 \\
\hline & Sudan & Uganda & 150,000 & & Sudan & Zaire & 32,000 \\
\hline & Chad & Sudan & 5,000 & & Ethiopia & Sudan & 700,000 \\
\hline & Zaire & Sudan & 8,000 & & Sudan & Zaire & 32,000 \\
\hline \multirow[t]{5}{*}{1984} & Sudan & Ethiopia & 39,000 & & Others & Sudan & $26,500^{*}$ \\
\hline & Ethiopia & Sudan & $484,000^{*}$ & 1992 & Sudan & Central African Rep. & 8,000 \\
\hline & Uganda & Sudan & 200,000 & & Sudan & Ethiopia & 1,500 \\
\hline & Chad & Sudan & 1,000 & & Sudan & Kenya & 92,000 \\
\hline & Zaire & Sudan & 5,000 & & Sudan & Uganda & 75,000 \\
\hline \multirow[t]{5}{*}{1985} & Sudan & Ethiopia & 72,000 & & Sudan & Zaire & 104,000 \\
\hline & Ethiopia & Sudan & $718,000^{*}$ & & Ethiopia & Sudan & 690,000 \\
\hline & Uganda & Sudan & $250,000^{*}$ & & Chad & Sudan & 27,000 \\
\hline & Chad & Sudan & 121,000 & $1993^{*}$ & Sudan & Central African Rep. & 17,000 \\
\hline & Zaire & Sudan & 5,000 & & Sudan & Ethiopia/Eritrea & 16,000 \\
\hline \multirow[t]{4}{*}{1986} & Sudan & Ethiopia & 110,000 & & Sudan & Kenya & 20,000 \\
\hline & Ethiopia & Sudan & $656,000^{*}$ & & Sudan & Uganda & 90,000 \\
\hline & Chad & Sudan & $93,000^{*}$ & & Sudan & Zaire & 120,000 \\
\hline & Uganda & Sudan & $165,000^{*}$ & & Others & Sudan & $20,500^{*}$ \\
\hline \multirow[t]{3}{*}{1987} & Ethiopia & Sudan & 677,000 & & \multirow{3}{*}{\multicolumn{3}{|c|}{$\begin{array}{l}\text { * Estimates vary widely } \\
\text { Source: World Refugee Survey (various issues) }\end{array}$}} \\
\hline & Sudan & Ethiopia & 205,000 & & & & \\
\hline & Uganda & Sudan & 90,000 & & & & \\
\hline
\end{tabular}


been suicidal because those fleeing from the South would have had to penetrate northern Sudan before legally becoming refugees. Therefore, the absence of informal networks, the location of the major conflict and the inaccessibility of international borders explain why southern Sudanese refugees did not flee to Chad, Egypt and the Gulf states. ${ }^{18}$

Another factor that affected where and how many refugees, and the internally displaced fled (see table 2), was the military and political policy of control devised and implemented by both the SPLA and the Sudanese army. For instance, by mid-1987, the atrocities committed against unarmed civilians by both the SPLA and government troops, made it impossible for southern Sudanese to either relocate to areas under SPLA control or to cross international borders near the SPLA sphere of influence. $A$ case in point was the movement of over one million southern Sudanese to the unfriendly territory of Khartoum during the SPLA reign of terror in the South. Having lost faith in the SPLA's ability to protect them from its own atrocities and those of the state, the people decided that they would rather die trying to reach some relief assistance in the North. The SPLA policy of "protecting" the internally displaced and potential refugees in its area of control, for political and

Table 2: Estimated Number of Internally Displaced Persons in the Sudan

$\begin{array}{rr}\text { Year } & \text { Number } \\ 1987 & \mathbf{1 , 5 0 0 , 0 0 0} \\ 1988 & \mathbf{2 , 0 0 0 , 0 0 0 - 3 , 2 0 0 , 0 0 0} \\ 1989 & \mathbf{2 , 0 0 0 , 0 0 0 - 3 , 2 0 0 , 0 0 0} \\ 1991 & \mathbf{4 , 5 0 0 , 0 0 0} \\ 1992 & \mathbf{4 , 7 5 0 , 0 0 0} \\ 1993^{*} & \mathbf{5 , 0 0 0 , 0 0 0}\end{array}$

"Only part of 1993.

Source: World Refugee Survey, various issues.

Note: Reported numbers vary widely for most periods. The estimates depend on who counts, how, when and why. military reasons, and to prevent unsanctioned cross-border flight, also made it extremely difficult for southern Sudanese to escape from the violence. Indeed, each time a mass refugee flow occurred, it was largely because the SPLA was losing military control over a given area. It is, equally important to remember that both parties to the conflict controlled internal and refugee movements. ${ }^{19}$

Migration to Egypt and the Gulf states depended largely on the existing socioeconomic and political conditions in the country of origin; the history of contacts prior to and during flight; and linkages between the Sudan and those countries; proximity; and the asylum, labour and migration policies of host countries. Egypt, which had been a colonial power, an ally and agent of British colonialism and a subneo-colonial power in the Sudan, built institutional linkages with the northern part of the country. These linkages, especially in the fields of military, education, religion, culture, administration and finance, encouraged limited migration from the North to Egypt. Three factors explained why very few Sudanese migrated and/or sought asylum in Egypt. First, most of the people who went to Egypt were students and government officials who were sent by the Sudanese government. Some of the Sudanese overstayed and/ or used well developed institutional linkages between Egypt and the West to migrate to the industrialized countries. Further, there were no job markets in Egypt to encourage mass migrations because Egypt itself was sending skilled administrative labour to the Sudan. Also, Egypt had to rely heavily on the West to address its serious socioeconomic and political crisis. Second, Egypt's interest in the security of the Nile dictated an overall nonconfrontation policy towards the Sudan. In that respect, it could not afford to become a major asylum country without jeopardizing its security interests in the Sudan. Finally, the South, which generated the bulk of refugees and internally displaced persons, was cut off from Egypt's immediate bor- der. Equally, no viable institutional linkages were developed with the South during and after the colonial period. On somewhat of a different note, Egypt as a surrogate power, barricaded the Sudan from the West, thus stifling the development of institutional linkages between the Sudan and the West; linkages that could have encouraged migrations and/or flight to the West. ${ }^{20}$

Migrations to the Gulf states were influenced by internal and external, as well as push and pull factors. In the late 1980 s and early 1990 s, a number of developments curtailed migrations from the Sudan and other countries including Egypt; Syria, Jordan, Sri Lanka, India, Pakistan, Bangladesh, Thailand, Indonesia, Taiwan and the Philippines. First, the oil-rich countries imposed new labour and migration policies. The primary objectives of the policies were to control illegal or clandestine migrations and reduce the rapid growth of migrant labour communities in the host countries. Second, the oil boom had evaporated, and as a result, the need for cheap foreign labour drastically declined. Finally, the rise of Islamic fundamentalism such as in the Sudan, threatened the political status quo of the moderate Arab states of Saudi Arabia and Kuwait. Opportunities in the Gulf were further reduced by the Gulf War and the controversial "humanitarian intervention" in Iraq. These factors collectively made it increasingly difficult for Sudanese to gain access to the shrinking and unstable labour market in the region. With the data presently available it is difficult to provide a conclusive view on the socioeconomic and political effects of the decline in regional migration. However, by examining the labour remittances to the country which stood between 1.3-1.4 billion Sudanese $£$ in 1987 , it can be inferred that the economic impact was devastating to the national economy. ${ }^{21}$

\section{Refugee Migrations to the Industrialized States of the North}

The refugee movements from the Sudan to the industrialized countries of 
the north accounted for a very small proportion of the uprooted. The movements of population were influenced by: formal and informal institutional linkages, migration and asylum policies of the industrialized countries, socioeconomic and political conditions in the industrialized countries, physical distance from industrialized countries, occupation, and the capacity to exit from the Sudan and/or from a first country of asylum in Africa.

\section{To Europe}

As noted above, Britain was a colonial power in the Sudan. However, it did not develop viable institutional linkages with the country for a number of reasons. The North was ruled by Egypt under the tutelage of the British colonial power. Later, even when a handful of northern Sudanese became colonial administrative agents, they were still somewhat barricaded from Britain by Egypt. As a result, no independent and viable institutional linkages were built between northern Sudan and Britain. This is not to deny the existence of rudimentary linkages in areas of education and finance in the immediate colonial era. On the southern front, there was no effective colonial presence. Furthermore, the "Closed Door" policy practised in the area prevented the penetration of colonial and international finance capital. As such, the only institutional linkages which existed between southern Sudan and the outside world were those religious and educational institutions created mainly by Christian religious organizations from Britain and Canada. In a nutshell, no institutional linkages which could facilitate mass migration existed.

By formal the end of colonialism, Britain was in a state of political and economic decline, thus making it impossible to build strong linkages with the Sudan. Further, wartorn southern Sudan remained predominantly a peasant society, tied to the land and never contemplating resettlement in a faraway country. Most of the refugees fled without any material resources, and hence they did not have the capacity to go and/or send their children to Britain. Furthermore, asylum and mi- gration to Britain did not guarantee the recognition and admission of southern Sudanese as refugees. Indeed, recent implementation of asylum and migration policy, including attempts to harmonize policies in Europe, made it increasingly difficult for people from developing countries to seek asylum and/or migrate to Britain and the rest of the European Economic Community. Those Sudanese who managed to get to Britain were either students, (exgovernment officials, military personnel, or Christian religious ministers. These people were supported in their migration or flight by nongovernmental organizations such as the World University Services (UK), Pilkington Charitable Trust, UNHCR, OXFAM (UK) and church and relief organizations. Formal contacts that some of the refugees had developed either prior to, or during, their flight were also utilized. There were also those who managed to get to Britain because of kinship and family networks. ${ }^{22}$

Tables 3 and 4 show the number of Sudanese and Ghanaians who claimed

\begin{tabular}{|c|c|c|c|c|c|c|c|c|c|c|c|}
\hline \multirow[b]{2}{*}{ Origin } & \multicolumn{11}{|c|}{ Table 3: Refugees Granted Asylum or Refugee Status in the U.K. ( By country of origin 1982-1991) } \\
\hline & 1982 & 1983 & 1984 & 1985 & 1986 & 1987 & 1988 & 1989 & 1990 & 1991 & Total \\
\hline Ghana & 0 & 199 & 73 & 89 & 72 & 47 & 39 & 35 & 5 & 10 & 569 \\
\hline \multirow[t]{2}{*}{ Sudan } & 3 & 2 & 2 & 6 & 1 & 11 & 34 & 60 & 5 & 5 & 129 \\
\hline & \multicolumn{11}{|c|}{$\begin{array}{l}\text { Table 3a: Refugees Granted Exceptional Leave to Remain } \\
\text { (By country of origin 1982-1991. Dependents included up to 1989.) }\end{array}$} \\
\hline Origin & 1982 & 1983 & 1984 & 1985 & 1986 & 1987 & 1988 & 1989 & 1990 & 1991 & Total \\
\hline Ghana & 12 & 126 & 59 & 48 & 49 & 115 & 113 & 110 & 30 & 20 & 682 \\
\hline \multirow[t]{2}{*}{ Sudan } & 0 & 1 & 0 & 0 & 23 & 7 & 1 & 5 & 5 & - & 42 \\
\hline & \multicolumn{11}{|c|}{$\begin{array}{l}\text { Table 3b: Refusals of Asylum, Refugee Status or Exceptional Leave to Remain } \\
\text { (By country of origin 1982-91. Dependents included up to 1989.) }\end{array}$} \\
\hline Origin & 1982 & 1983 & 1984 & 1985 & 1986 & 1987 & 1988 & $1989^{t}$ & $1990^{+}$ & $1991^{t}$ & Total \\
\hline Ghana & 28 & 199 & 157 & 252 & 40 & 197 & 58 & 20 & 50 & 70 & 981 \\
\hline \multirow[t]{3}{*}{ Sudan } & 0 & 3 & 5 & 8 & 10 & 14 & 1 & 5 & 5 & 5 & 56 \\
\hline & \multicolumn{11}{|c|}{ Table 3c: Applications at Port of Entry in Country (by nationality 1990-1991) } \\
\hline & \multicolumn{7}{|c|}{$1990^{+} \quad 1991^{+}$} & & & & \\
\hline Country & Total & At Port & In-country* & Total & At port & Inz- & untry* & & & & \\
\hline Ghana & 1020 & 90 & 930 & 2405 & 195 & & 2210 & & & & \\
\hline Sudan & 255 & 10 & 245 & 1150 & 70 & & 1085 & & & & \\
\hline \multicolumn{12}{|c|}{$\begin{array}{l}\text { ' Figures rounded to the nearest } 5 \text {. In-country figures and totals may be under-recorded } \\
\text { "In-country figures include a small number of applications recorded as having been made overseas and referred to the } \\
\text { Home Office for decision. } \\
\text { Sources: Refugee Council, UK Asylum Statistics 1982-1992. London: The Policy and Information Division, Refugee Council: 12, 14-16, 18. }\end{array}$} \\
\hline
\end{tabular}




\begin{tabular}{|c|c|c|c|c|c|c|c|c|}
\hline \multicolumn{9}{|c|}{$\begin{array}{l}\text { Table 4: Applications Received in the UK for Asylum } \\
\text { (excluding dependents, by nationality, 1985-1991) } \\
\text { Number of Principal Applicants }\end{array}$} \\
\hline Nationality & 1985 & 1986 & 1987 & 1988 & $1989 t$ & $1990^{\dagger}$ & $1991^{+}$ & Total \\
\hline Ghana & 141 & 196 & 125 & 172 & 330 & 1020 & 2405 & 4389 \\
\hline Sudan & 16 & 18 & 20 & 22 & 110 & 255 & 1150 & 1591 \\
\hline \multicolumn{9}{|c|}{$\begin{array}{l}\text { 'Provisional figures rounded to the nearest } 5.1990 \text { figures may underestimate because of } \\
\text { delays in recording. } \\
\text { Source: British Home Office Statistical Bulletin. London: Research and Statistics Department, } \\
\text { June 24, 1992: Table 2.1. }\end{array}$} \\
\hline
\end{tabular}

asylum in the UK. The comparative data supports the main thrust of the arguments about factors which influenced the refugee flows from the Sudan. To begin with, both countries were former British colonies. However, there were marked differences between them. First, colonial and postcolonial institutional linkages between Ghana and Britain were well developed. The middle class was also comparatively well developed in Ghana. As we have noted with the Sudan, the opposite was and still is the case. Second, the duration and intensity of political violence, and economic and ecological crisis were far more pronounced in the Sudan than in Ghana. Third, the capacity to exit and reach Britain either by flying directly or through another country was much better in the case of Ghanaians. Indeed, some went on study and official or unofficial visits. The Sudan, for that matter southern Sudan, did not have a similar capacity. Fourth, Ghanaians developed complex and viable informal migration networks between Britain and their home country. Such networks are not available in the case of the Sudanese. Recently, however, Sudanese refugees started building their informal networks with the U.K. Finally, the implementation of asylum and refugee policy, for the most part, was fairly uniform. Recently, however, the policy became stricter on Ghanaians, yet their movements continue to be significant. ${ }^{23}$

Flight to the rest of Europe was also constrained by lack of strong institutional linkages, unfavourable asylum and migration policies, and the incapacity to exit and reach European countries. Since there is inadequate data at this point in the research, only general observations will be made. First, there is a small and scattered population of Sudanese refugees in European countries such as Belgium, Finland and Greece. Most of them went to these countries mainly through the assistance of European based NGOs. More often than not, members of this group spent many years "strategizing" and trekking from one country to the next before reaching their final destination. Others went on official tour and/or to study and decided to seek asylum. An important point is that existing institutional linkages facilitated this limited migration. The linkages, however, were too weak and too young to generate and sustain mass migrations. Second, generally, both the Cold War and post-Cold War asylum and migration policies in Europe exhibited a very high level of racial discrimination toward Africans and other peoples from the underdeveloped world. This has been compounded by the socioeconomic crisis, the feverish growth of xenophobia in Europe and the efforts by the EEC to harmonize their asylum and migration policies. It is, however, not clear to what extent the policies of refugee and migration deterrence have managed to further curtail refugee flows from the Sudan. Finally, refugees from the Sudan who could barely survive in the overcrowded and famine-like settlements in the neighbouring African states, could not afford air tickets to Europe to make in-country claims. This, however, must be qualified because a few young [male] Sudanese refugees did show their ability to struggle against numerous odds to reach some industrialized countries. It should also be noted that very weak formal institutional linkages developed between the USSR and the Sudan, especially in the field of technical and military cooperation. However, those Sudanese who went under such arrangements and decided to seek asylum, had to go to other European countries or North America because of the strict immigration policies of the USSR. $^{24}$

\section{To North America}

Refugee and migration movements from the Sudan to North America are recent developments (see tables 5 and 6). During the Cold War, the USA provided military and financial support to Khartoum, thus creating some dependent institutional linkages. These linkages were essentially between the northern-based government and the USA. As such, the linkages could not be utilized by the majority of the southern Sudanese refugees. As noted above, the development of stronger neocolonial ties were hampered by the uneasy relations between the two governments. Furthermore, since Egypt became its most reliable client state and the regional centre for the U.S. military, cultural and financial activities, it was thought that through Egypt, institutional networks would be built to incorporate and/or contain the Sudan. This strategy did not work largely because the actions of the ruling regimes of the Sudan often contradicted American hegemony. The failure of U.S. financial, military, cultural, ideo-

\begin{tabular}{|c|c|c|c|c|c|c|c|c|c|c|c|}
\hline \multicolumn{12}{|c|}{ Table 5: Refugee Arrivals in the U.S. from the Sudan, 1983-92 } \\
\hline Year & 1983 & 1984 & 1985 & 1986 & 1987 & 1988 & 1989 & 1990 & 1991 & 1992 & 1983-92 \\
\hline claims & 4 & 0 & 3 & 0 & 2 & 1 & 6 & 59 & 6 & 127 & 208 \\
\hline
\end{tabular}

Refuge, Vol. 13, No. 8 (January 1994) 
logical and political capital to penetrate the Sudan provides some explanation for the weakness of the formal networks which could not sustain refugee flight to the USA. Another important factor in the direction of flight was the U.S. asylum and migration policies which have been largely antiAfrican. Finally, the essentially Western-sponsored UNHCR policy which discourages resettlement to a third country also curtailed the resettlement of Sudanese refugees in the U.S. As a result of these factors, including their inability to reach U.S. ports, very few Sudanese settled in the U.S. The majority of those who resettled in the U.S. went as students and government officials. There were also those selected for resettlement from overseas and those sponsored by NGOs or through their informal contacts. Another group came under the U.S. family reunification admission policy. ${ }^{25}$

Migrations and refugee flows to Canada were influenced by Canada's role as a non-colonial middle power state; its membership and participation in the Commonwealth and the UN organizations; its support for the Southern African Development Conference (SADC); its physical distance from the Sudan; its migration and asylum policies; the provision of relief and development assistance; and the absence of Canadian consular services in areas of major refugee settlements. Other factors were the inability of the overwhelming majority of refugees to make it to Canadian ports and their "decision" to stay close to their home country. ${ }^{26}$

Canada's interests and influence in Africa are recent and date back to the late 1950s and 1960s when the struggle for formal decolonization had gained irreversible momentum on the continent. R.O. Mathews explained Canada's neo-realist policy:

Despite the rhetoric of government officials, Africa has always been of marginal interest to Canada; our policies towards Africa were designed not so much to serve the needs of African states as the interests of Canada which, in any case were only indirectly related to Africa. Indeed our interests in Africa were, at least initially, derived in large part from our broader concern to maintain a strong and united alliance with the West (including Britain, France and Portugal) against the Soviet bloc; from desire to foster the growth of the Commonwealth; from necessity to search out markets for Canadian goods and services and outlets for Canadian investment; and from a deeply felt need to sustain a favourable image of Canada as a nonracist and forward-looking state. ${ }^{27}$

Such a policy led to the expansion of military, technical, capital and relief assistance to many countries in Africa, including the Sudan. The main beneficiaries of this policy in nonFrancophone Africa, however, were Nigeria, Angola, Mauritius, Ghana, Kenya and South Africa. As far as the Sudan was concerned, these linkages were too weak to facilitate major refu- gee flows to Canada, partly reflecting the fact that they were largely the work of NGOs. ${ }^{28}$

Since 1967, Canada's asylum and migration policy has undergone a serious and positive surgical change. However, the lack of Canadian embassies located in the region where most of the Sudanese refugees resided, and the strict selection criteria which emphasized age, language (English or French), education, occupation and kinship ties, largely worked to the disadvantage of the majority of the uprooted. Two factors which somewhat cushioned the negative effects of the policy were the absence of visa requirements for Sudanese, and the media, NGOs and public sympathy with the crisis since the 1980s. What the policy meant in practice was that those who could manage to reach ports of entry into Canada were almost assured of being granted asylum. By default, this policy strengthened informal networks which in turn progressively facilitated limited refugee flows. For the majority of those who lacked informal networks and could not afford to reach Canada, their fate rested in the hands of the UNHCR and with the Canadian overseas selection process. As table 6 shows, very few Sudanese managed to resettle in Canada. ${ }^{29}$

\section{Conclusion}

The foregoing analysis suggests that the main causes and persistence of refugee flows from the Sudan were: colonial violence; racial, religious, eth-

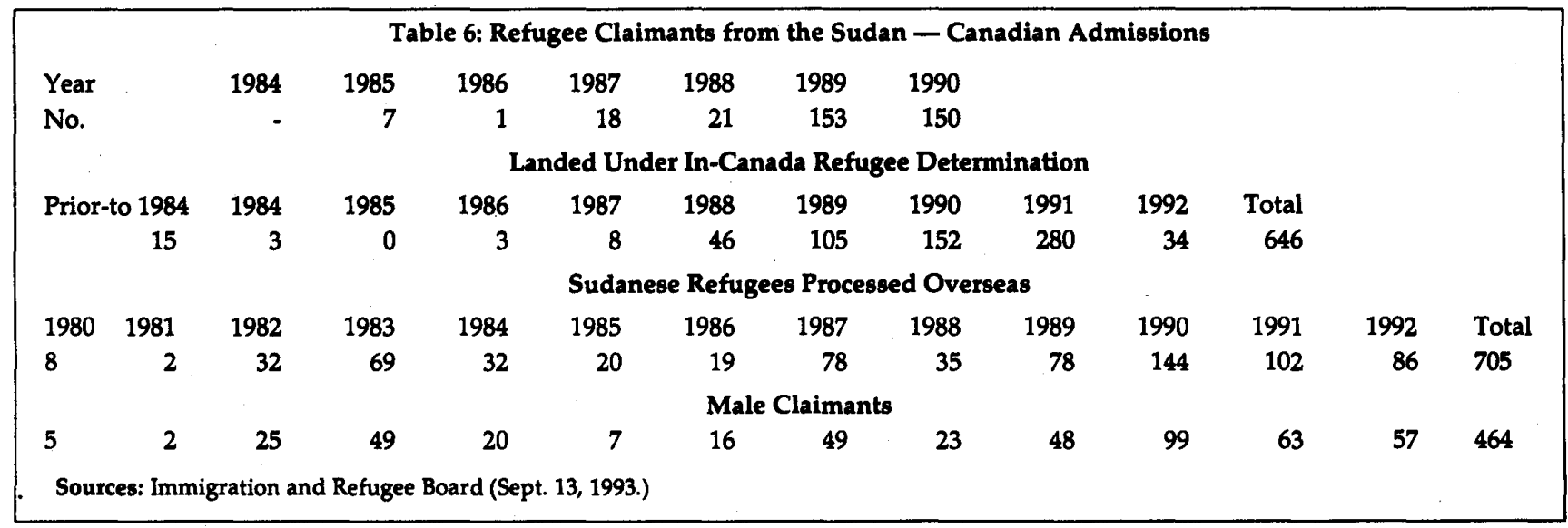


nic and ideological violence; the uncivil nature of the postcolonial state; external interventions, especially by the superpowers, the Arab states and Israel; and ecological violence. Economic underdevelopment and economic crisis also fuelled political conflict which resulted in and has sustained refugee flows and internal displacement. In retrospect, there is no rigid dichotomy between economic and political, political and ecological, internal and external, past and present factors, forced and unforced migration. Also, the post-Cold War politics of "order" and "the right to stay" perpetuate violations of human rights and sustain the crisis. It has also been argued that refugees fled their home country only when they had exhausted every conceivable coping strategy. The intensity, timing, duration and location of violence, the history of violence and flight, physical capability and capacity to flee, and individual and collective responses to the crisis were also important considerations in the timing of flight. On the question of the modes of flight, it is suggested that the majority of refugees trekked across the hostile terrain to international borders. There were a few who used a combination of means of transportation, especially those who moved from one country to the next. The means of transportation was determined by the nature, location, timing and duration of violence and access to other options of travel. Where the refugees went was influenced by a number of related factors: proximity and accessibility to international borders, informal and formal institutional networks, the location of violence, preflight occupations of the refugees, national and international politics and asylum and migration policies of host countries. It is maintained that these factors explain why the overwhelming refugee population from the Sudan circulated within the neighbouring African states. Also, it is pointed out that the neighbouring states were themselves quite poor and involved in the population exchange. This point generally highlights the myth and the reality of the concept of a "refuge" in the context of wartorn, ecologically weak and chronically poor African countries. It is, therefore, clear that unless the causes of the human tragedy are addressed, the plight of Sudanese refugees and the internally displaced will continue unabated.

\section{Notes}

1. See, for example,M. Abdel-Rahim, Changing Patterns of Civil-Military Relations in the Sudan. Uppsala: Scandinavian Institute of African Studies, 1978; A.Z.A.R. Ahmed, et al., War Wounds: Development Costs of Conflict in Southern Sudan. London: Panos Institute, 1988; H. Assefa, Mediation of Civil Wars: Approaches and Strategies in the Sudan Conflict. Boulder, Colo.: Westview Press, 1987; G. Morrison, The Southern Sudan and Eritrea: Aspects of Wider African Problems. London: Minority Rights Group, 1971.

2. See A.R. Zolberg, A. Suhrke and S. Aguayo, Escape from Violence: Conflict and Refugee Crisis in the Developing World. New York: Oxford University Press, 1989: 50-56, 103-120, 122; Zolberg, "The Refugee Crisis in the Developing World: A Close look at Africa," in G. Rystad, ed., The Uprooted: Forced Migrations as an International Problem in the PostWar Era. Lund, Sweden: Lund University Press, 1990: 110-116; M: Bulcha, Flight and Integration: Causes of Mass Exodus from Ethiopia and Problems of Integration in the Sudan. Uppsala: Scandinavian Institute of African Studies, 1988; H.E. Harrell-Bond, Imposing Aid: Emergency Assistance to Refugees. Oxford: Oxford University Press, 1986; P.B. Henze, The Horn of Africa: From War to Peace. New York: St. Martin's Press, 1991;L. Timberlake, Africa in Crisis: The Causes, the Cures of Environmental Bankruptcy. London: Earthscan Publications, 1988; P. Gibbon, Y. Bangura and A. Ofstad, eds. Authoritarianism, Democracy and Adjustment: The Politics of Economic Reform in Africa. Uppsala: Scandinavian Institute of African Studies, 1992; The World Bank, The World Bank Annual Report, various issue, especially 1983: 65-68; 1984: 79-84; 1985: 85-91; 1986: 79-84; 1987: 75-82; 1989: 105-113; 1991: 109-116; 1992: 111-119; U.S. Committee for Refugees, Washington, D.C.: World Refugee Survey, various issue; Africa Confidential, London, various issue; T. Wallace, Displaced Labour: $A$ Study of Employment Among Educated Refugees from the Horn of Africa. London: WUS(UK), 1986; I. Serageldin, et al., Manpower and International Labour Migration in the Middle East and North Africa. Oxford University Press, 1983: 6, 14, 48, 59, 68-69, 71, 82; European Consultation on Refugees and Exiles, Report of ECRE Biannual General Meeting. Geneva: ECRE, October 1992.

3. See, for example, A.A. Boahen, ed., General History of Africa. California: James Currey, 1990: 39; P.E. Lovejoy, Transformations in
Slavery: A History of Slavery in Africa. London: Cambridge University Press, 1983: 1518, 147-150; D. Austin, "Africa Repartitioned?", Conflict Studies, 193: 6-7; P. Woodward, "War - or Peace - in North-East Africa," Conflict Studies, 219: 7-8.

4. See R. Robinson and J. Gallagher, Africa and the Victorians: The Official Mind of Imperialism. London: Macmillan Press, 1974; Boahen, Ibid: 41-2; G.N. Sanderson, England and Europe and the Upper Nile, 1882-1889. Edinburgh: Edinburgh University Press, 1965; J.S. Galbraith, "The Trial of Arabi Pasha," Journal of Imperial Commonwealth History, VII (1979): 274-292; A.G. Hopkins, "The Victorians and Africa: $A$ Reconsideration of the Occupation of Egypt, 1882," Journal of African History, 27 (1986): 363-391.

5. See J. Markakis, National and Class Conflict in the Horn of Africa. Cambridge: Cambridge University Press, 1987: 146.

6. Ibid: 76

7. Ibid: 77-8, 149-156.

8. Ibid.

9. Ibid: 80-86, 157, 160; P. Woodward, "Rivalry and Conflict in North-East Africa," Conflict Studies, 199: 2-6; Woodward, War - or Peace - in North-East Africa?" op. cit: 8; D.G. Morrison, et al., Black Africa: A Comparative Handbook. New York: The Free Press, 1972: 347.

10. R.O. Collins, Eastern African History. New York: Markus Wiener Publishing, 1990: 177. 194; Zolberg, Suhrke and Aguayo, Escape from Violence, op. cit.: 52-55; P. Woodward, "Rivalry and Conflict in the North-East Africa," Conflict Studies, 199: 2-5; "War - or Peace - in North-East Africa?" op. cit: 8-10; C. Legum, "The Horn of Africa: Prospects for Political Transformation," Conflict Studies, 254: 8-9; Harrel-Bond, Imposing Aid, op. cit: 36-7.

11. Woodward, "War - or Peace - in North-East Africa," Ibid: 9-11; C. Legum, ed., Africa Contemporary Record. New York and London: Africana Publishing Company, 1986-1987: B565-B592.

12. J. Oyediran and P. Hunt, Evidence of Torture in Africa. UN Special Rapporteur on Torture. Occasional Paper No. 2 September 1991: 18 21; Legum, "The Horn of Africa: Prospects for Political Transformation," op. cit: 8-11; World Refugee Survey, 1992: 40-42; World Refugee Survey, 1993: 62.

13. Woodward, "War - or Peace," op. cit. 9-10; Austin, Africa Repartitioned?" op. cit: 7; Personal Interviews with Sudanese refugees in Kenya, the UK and Canada (May 1992 to November 1993).

14. I. Serageldin, et al., Manpower and International Labour Migration in the Middle East and North Africa. op. cit: 6, 14,48, 59, 68-69,71,82; Personal Interviews, Ibid.

15. Personal Interviews. For a somewhat similar finding see, P.H. Refugee From Revolution: U.S. Policy and Third-World Migration. Boulder, Colorado: Westview Press, 1991: 45-49. 
16. World Refugee Survey, various issues; The author has witnessed a number of refugee migrations from the Sudan to Uganda and Kenya; Interviews.

17. Austin, "Africa Repartitions?" op. cit: 7; Harrell-Bond, Imposing Aid, op. cit: 36-38; A. Omara-Otunnu, Politics and the Military in Uganda, 1890-1985. New York: St. Martin's Press, 1987: 92-144; 175-181; Personal Interviews with Ugandan returnees and officials providing refugee assistance in southern $\mathrm{Su}$ dan (1989-1993); Refugee Policy Group, Older Refugee Settlements in Africa. Washing. ton, D.C.: RPG, 1985: 126.

18. Woodward, "Rivalry and Conflict in NorthEast Africa", op. cit: 8-9; World Refugee Survey, various issue; Personal Interview with Sudanese refugees (1992-1993).

19. Legum, ed., Africa Contemporary Record, op. cit: 8593-596; World Refugee Survey, op. cit., Ibid; Personal Interviews with Sudanese Refugees (1992-1993).

20. See, for example, Woodward, "Northern Africa and the Horn," op. cit: 7; Discussions with Sudanese Refugees in Oxford, England (October 1993).

21. Legum, ed. Africa Contemporary Record, op. cit: B593. See also, Seregeldin, et al., Manpower and International Labour Migration in the Middle East and North Africa, op. cit: 10 M.M. Kritz and H. Zlotnik, "Global Interactions: Migration Systems, Processes and Policies," in M.M. Kritz, L.L. Lim and H. Zlotnik, eds., International Migration Systems: A Global Approach. Oxford: Clarendon Press, 1992: 1-11; J. Salt, “A Comparative Overview of International Trends and Types, 19501980," International Migration Review, XXII, 3 (Fall 1989): 444.

22. See for example, Report of European Consultation on Refugees and Exiles, op. cit: 10-133; Asylum in Europe: $A$ Handbook for Agencies Assisting Refugees, 1983; R. Kaye and R. Charlton, "United Kingdom Refugee Admission Policy and the Politically Active Refugee," Research Paper in Ethnic Relations, Coventry: University of Warwick, 13 (1990); Home Office, Asylum Process Must Not Be Stifled By Bogus Applications, Says Charles Wardle, London, 289/92 (1992); Amnesty International (British Section), United Kingdom: Deficient Policy \& Practice for the Protection of Asylum Seekers. London: Amnesty (1991); United Kingdom, Passing the Buck: Deficient Home Office Practice in "Safe Third Country" Asylum Cases. London: Amnesty British Section, nd.; Commons Debates, London (September 2, 1987): 8715-8725; Asylum Seekers and Refugees (May 8, 1991): 746-752; K. Lowe, Britain's Forgotten Prisoners. London: Detention Advice Service, n.d.; Home Office, Immigration, Nationality and Passports. London: Home Office (1988-89); ND: The Deportation of Refugees, unpublished paper deposited at the Refugee Studies Programme, Oxford University, Oxford, England; Home Office, Asylum Statistics: United Kingdom, 1990-91. London: Home Office (June 24, 1992); Refugee Council, UK Asylum
Statistics, 1982-1992. London: Policy and Information Division, Refugee Council (November 1992); $P$. Gordon, Policing Immigration: Britain's Internal Control. London: Pluto Press, 1985.

23. See B. Beckman, "Empowerment or Repression?: The World Bank and the Politics of African Adjustment," in Gibbon, Bangura and Osfstad, eds., Authoritarianism, Democracy and Adjustment, op. cit: 83-126; C. Flinterman, Human Rights in Ghana. Geneva: International Commission of Jurists, SIM Special No. 4 ; Wallace, Displaced Labour: A Study of Employment Among Educated Refugees from the Horn of A frica, op. cit, Ibid; Home Office, Asylum Statistics: United Kingdom, 1990-91. Ibid; Refugee Council, UK Asylum Statistics, 1982-1992, Ibid; Personal Interviews with Sudanese and Ghanaians and NGOs assisting refugees in the UK (October, 1993). See also, A. Adepoju, "South-North Migrations: The African Experience," International Migration, XXIX 2 (June 1991): 205221.

24. Wallace, Displaced Labour. Ibid; Report of European Consultation on Refugees and Exiles, op. cit: 10-133; Asylum in Europe: A Handbook for Agencies Assisting Refugees, op. cit. Ibid; World Refugee Survey, various issue; $P$. Cleary, Human Rights and the Admission of Refugees: the British Case. (1989), Unpublished, deposited at the Refugee Studies Programme, Oxford: 1-3.

25. International Organization for Migration, South-North Migration. Geneva: IOM, Document No. 4.1 (December 1990): 3-5; Koehn, Refugees from Revolutions, op. cit; Church World Service, Distributed by the Church World Service upon receipt from the U.S. Department of State 01/1/1986, n.d.: 70; World Refugee Survey, various issue.

26. See, for example, R.O. Mathews, "Canada and Anglophone Africa," in P.V. Lyon and T.Y. Ismael, eds., Canada and the Third World. Toronto: Macmillan, 1976: 61, 91; D.B. Dewitt and J.J. Kirton, Canada as a Principal Power: A Study in Foreign Policy and International Relations. Toronto: John Wiley \& Sons, 1983: 1-84; CIDA, Sharing Our Future: Canadian Development Assistance. Quebec: CIDA, 1987; Canadians and International Development, 1968-1988. Ottawa: CIDA, 1988.

27. Mathews, Ibid: 61 .

28. Ibid: 94-97; Statistics Canada, Trade of Canada, Ottawa, 1972-1992.

29. H. Adelman, "Canadian Refugee Policy in the Postwar Period: An Analysis," in H.Adelman, ed. Refugee Policy: Canada and the United States. Toronto: York Lanes Press, 1991: 173-176, 182, 185-186, 193-194. Personal Interviews with Sudanese refugees in Kenya and Canada (1992-1993). Visitor Visa Requirements were imposed on citizens of the following countries: Colombia, Nigeria and Pakistan (June 22, 1977), South Africa (April 10, 1978), Cuba, Ecuador, El Salvador, Ghana and Uganda (September 28, 1978), Chile (December 28, 1979), Haiti (September 25,1980 ), India (October 15, 1981), Bangladesh and Sri Lanka (September 8, 1983), etc.

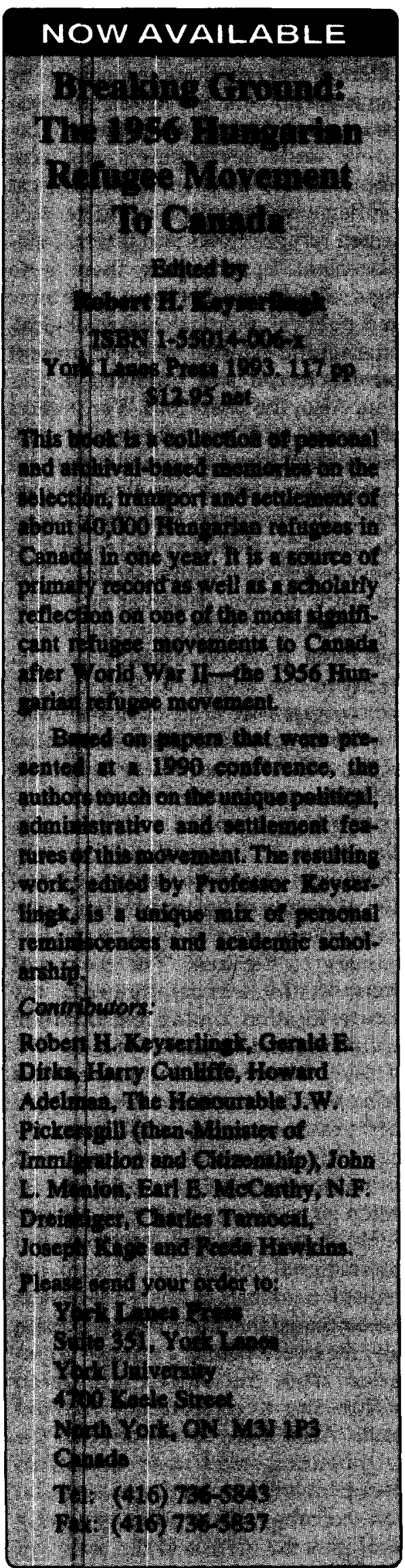

